\title{
Genetic Diversity of Cassava (Manihot esculenta Crantz) in Ecuador by Using SSR Markers
}

\author{
Nelly Paredes ${ }^{1}$, Valeria Alulema ${ }^{2}$, Luis Lima ${ }^{1}$, Marten Sørensen ${ }^{3 *}$, and Álvaro Monteros-Altamirano ${ }^{4}$ \\ 1 INIAP, Estación Experimental Central de la Amazonía, Vía Sacha San Carlos km 3 de la entrada a la Parker, \\ Orellana, Ecuador; nelly.paredes@iniap.gob.ec (N.P.); luis.lima@iniap.gob.ec (L.L.) \\ 2 UCE (Universidad Central del Ecuador) - INBIOMED (Instituto de Investigación en Biomedicina), Hospital \\ Docente de Calderón, Edificio CEGEMED, Quito, Ecuador; vealulema@uce.edu.ec / (V.A) \\ 3 Department of Plant and Environmental Sciences, Faculty of Science, University of Copenhagen, Sobi/Plen- \\ KU, Thorvaldsensvej 40, 3., DK-1871 Frederiksberg C, Denmark \\ * Correspondence: ms@plen.ku.dk \\ 4 INIAP, Estación Experimental Santa Catalina, Panamericana sur km 1, Quito, Ecuador; alvaro.monte- \\ ros@iniap.gob.ec (Á.M.-A.)
}

Abstract: Cassava (Manihot esculenta Crantz), domesticated in the Amazonian region of South America, presents an important diversity in Ecuador, where it is a main staple food; however, only few Ecuadorian cassava accessions have been included in international molecular assessments. The purpose of this study was to apply suitable cassava microsatellites to characterize the genetic variability of the Ecuadorian cassava collection composed mainly of local landraces from the Coast, Andes and Amazonia regions. The use of microsatellite markers allowed the determination of the genetic diversity of the collection. Seven selected SSR primers, permitted to identify homozygous and heterozygous materials within the cassava collection of 133 accessions. The loci presented an average genetic diversity value of 0.7 and an average PIC value of 0.67 , which is considered high. Low number of duplicates $(8.8 \%)$ were identified in the Ecuadorian collection which is not fully duplicated at CIAT. Currently, a wide range of cassava diversity is still cultivated in multi-crop agro-ecosystem, mainly in the Coast and Amazonian regions. Especially in the Amazonian region, due to important cultural uses of cassava by local ethnic communities, more in depth studies in the region could unveil the genetic diversity present in situ today.

Keywords: SSR; variability; ethnobotany

\section{Introduction}

In the Euphorbiaceae family, the genus Manihot contains 110 species ranging in habit from herbs to small trees [1,2]. Within this genus, cassava (Manihot esculenta Crantz) is the sixth major crop globally [1,3]. In the XI century, cassava was taken from Brazil to the Caribbean and Central America. In the XVI century, Portuguese took cassava to the west coast of Africa in the XVIII century, in the XIX century to the African east coast and from there onwards to India; the Spanish took cassava to the Pacific [4]. Nowadays, cassava is an important energy source in the diet of millions of people in tropical and subtropical areas of America, Asia and Africa [5,6]. As cassava grows under marginal conditions, it presents a great potential to increase food security in developing countries [1,7]. This species can be exploited as a root food crop, vegetable, feed, or industrial uses such as starch, ethanol, or bioplastics [6-8].

Cassava was domesticated somewhere between 3000 to 12000 B.C. in the Amazonian region of South America $[2,9,10]$. Archaeological evidence showed domestication in the Amazonia (5000 to 7000 B.C.) and use of cassava in the Peruvian coast before 4,000 BC; and Colombia and Venezuela from 3,000 to 7,000 B.C. [4,11]. According to Nassar [12] and 
Schaal et al. [1], there are two centers of diversity for the genus: one in Brazil and another in Mexico; however, domestication occurred from wild M. esculenta subsp. flabellifolia populations in the Brazilian Amazonia [1,13-17]. Cassava's primary gene pool (GP-1) comprises three subspecies, the cultivated M. esculenta subsp. esculenta and two wild progenitors M. esculenta subsp. flabellifolia and M. esculenta subsp. peruviana [17-19]. The closest wild relative is $M$. pruinosa [11]. It has also been determined that cassava is a functional diploid $(2 n=2 x=36)$ but probably a segmental allotetraploid $[2,7,20]$.

Genetic diversity of several national cassava collections has been studied by using different molecular techniques such as Isozymes for Costa Rica [21]; RAPDS for Ghana [22] and Venezuela [23]; SSR markers for Brazil [24-27] and Colombia [28]; SNP in Sierra Leone [29] and AFLP in Guyana [30]. In addition, evaluation of intercontinental collections has also been assessed, e.g. from America and several countries of Africa [31,32], America and Asia [33,34,35] and South America, Africa and Asia [36,37]. In spite of the important diversity of cassava present in Ecuador, only few Ecuadorian cassava accessions have been included in studies such as in Roa et al. [33,34]; Chavarriaga-Aguirre et al. [38], Kawuki et al. [31] and Raji et al. [36].

The purpose of this study was to apply suitable cassava microsatellites to characterize the genetic variability of the Ecuadorian cassava collection composed mainly of local landraces from the Coast, Andes and Amazonia regions, which have long been neglected in international studies.

\section{Materials and Methods}

\section{Plant materials of Cassava}

The cassava collection evaluated in this study is a subset of the landraces collected along with continental Ecuador, as explained in Monteros-Altamirano et al. [39]. This collection encompasses 136 accessions collected in the Coast, Andes and Amazonia regions of Ecuador. The Ecuadorian collection was planted at the Central Amazonian Experimental Station of INIAP, located at Via Sacha-San Carlos at $250 \mathrm{~m}$ a.s.l., with an average temperature of $24^{\circ} \mathrm{C}$ and average precipitation of $3100 \mathrm{~mm}$. Then, apical leaves samples, smaller than $1.5 \mathrm{~cm}$ in size, were taken for molecular characterization. Approximately 50 leaves were collected per accession in Ziploc bags with silica gel to avoid deterioration and allow the plant tissue to dry, allowing the sample to be preserved. The silica gel was changed every 24 hours for two days or until the leaf tissue was dehydrated.

\section{Extraction and quantification of DNA}

the sample in an Eppendorf tube and $1000 \mu$ l of prewarmed extraction buffer (CTAB $2 \%$, PVP 1\%, NaCl sodium chloride 1.4M, Tris-HCL pH8 0.1M, EDTA Ethylenediamine Tetraacetate Acid Disodium Salt pH8 0) were added, $2 \mathrm{M}$ and $2 \mu \mathrm{l}$ of $\$$-mercaptoethanol). The samples were incubated at $65^{\circ} \mathrm{C}$ in the water bath for one $\mathrm{h}$ with shaking every 30 minutes. Subsequently, they were centrifuged at $14000 \mathrm{rpm}$ for 10 minutes; then the supernatant was recovered and $750 \mu \mathrm{l}$ of CIA (Chloroform-Isoamyl Alcohol in proportion 4: 1). After shaking, it was centrifuged at $4000 \mathrm{rpm}$ for 15 minutes. The supernatant was recovered in a new tube, and again $750 \mu$ l of CIA was added, vortexed and centrifuged at $10,000 \mathrm{rpm}$ for 5 minutes. The supernatant was transferred to a new tube, $200 \mu \mathrm{l}$ of icecold ethanol was added and incubated at $-20^{\circ} \mathrm{C}$ for 30 minutes. It was centrifuged at 5000 rpm for one minute, after which the extracted DNA was captured. The obtained DNA was washed with 70\% ethanol, then the ethanol was removed, and the DNA was dried at temperature. The DNA pellet was re-suspended in $200 \mu \mathrm{l}$ of T.E. buffer with $2 \mu \mathrm{l}$ of RNAse enzyme $(10 \mu \mathrm{g} / \mathrm{ml})$ for every $100 \mu \mathrm{l}$ of DNA obtained. The samples were conserved until their quantification at $-20^{\circ} \mathrm{C}$. After DNA extraction, the concentration and quality of the DNA samples were determined. Samples were analyzed by using the BioTek Epoch TM microplate spectrophotometer. The Take3 microplate of the spectrophotometer consists of 16 wells, where $2 \mu$ Lblank (ultrapure water) were placed in the first two wells and $2 \mu \mathrm{L}$ 
DNA in each of the following wells. The reading was performed using the equipment software, and the data obtained were imported into an Excel table. Subsequently, the DNA was diluted at a concentration of $5 \mathrm{ng} / \mu \mathrm{L}$ with ultrapure water and tartrazine and stored at $-20^{\circ} \mathrm{C}$ for later use.

\section{Validation and amplification of DNA}

The extracted DNA samples were validated to determine their amplification capacity using microsatellite primer (SSRY5). The cocktail of the PCR reaction was: Buffer PCR (5X), MgCl2 (25mM), dNTP's (5mM), Primer (10uM) F, Primer (10uM) R, Taq polymerase $(5 \mathrm{U} / \mathrm{uL})$, DNA $(5 \mathrm{ng} / \mu \mathrm{L})$. After the amplification of the samples, $18 \mu \mathrm{L}$ of mineral oil was placed in each sample and amplified in the Basic Gradient thermocycler from Biometra. The amplification program included an initial cycle of denaturation at $94^{\circ} \mathrm{C}$ per $5 \mathrm{~min}, 30$ cycles of cyclical denaturation at $94^{\circ} \mathrm{C}$ per 45 seconds, 1 minute of binding at $55^{\circ} \mathrm{C}, 2 \mathrm{~min}$ cyclic elongation at $72^{\circ} \mathrm{C}$, and a final cycle of elongation at $72^{\circ} \mathrm{C}$ per $10 \mathrm{~min}$, to finally stabilizing at $10{ }^{\circ} \mathrm{C}$ for $5 \mathrm{~min}$ [41]. Seven primers (Table 1) taken from those proposed by Chavarriaga-Aguirre et al. [42] and Mba et al. [43] were applied. Primers were previously tested to determine different combinations: duplex 1 (SSRY40 and SSRY 153), duplex 2 (SSRY68 and SSRY31), duplex 3 (SSRY3 and SSRY151) and monoplex (SSRY100).

Table 1. Microsatellite primers used in the molecular analysis of the cassava collection.

\begin{tabular}{|c|c|c|c|c|}
\hline Locus & Motif & $\begin{array}{l}\text { Size } \\
(\mathrm{pb})\end{array}$ & Sequence & $\operatorname{MT}\left({ }^{\circ} \mathrm{C}\right)$ \\
\hline SSRY3 & (CA)17 & 250 & $\begin{array}{l}\text { 5' TTAGCCAGGCCACTGTTCTT 3' }^{\prime} \\
\text { 3' GCGAGGTTCAAATATGCGAT 5' }\end{array}$ & 55 \\
\hline SSRY31 & (GA)21 & 190 & $\begin{array}{c}\text { 5' CTTCATCACGTGTTAATACCAATC 3' } \\
3^{\prime} \text { ATTGTTGTGGTTGCAGGACA 5' }\end{array}$ & 55 \\
\hline SSRY40 & (GA)16 & 231 & $\begin{array}{l}5^{\prime} \text { TGCATCATGGTCCACTCACT 3' } \\
\text { 3' CATTCTTTTCGGCATTCCAT 5' }\end{array}$ & 55 \\
\hline SSRY151 & (GA)126 & 182 & $\begin{array}{c}\text { 5' AGTGGAAATAAGCCATGTGATG 3' } \\
\text { 3' CCCATAATTGATGCCAGGTT 5' }\end{array}$ & 45 \\
\hline SSRY68 & $\begin{array}{c}(\mathrm{CT}) 12 \\
(\mathrm{CCCT}) 17\end{array}$ & 290 & $\begin{array}{l}5^{\prime} \text { GCTGCAGAATTTGAAAGATGG 3' } \\
\text { 3' CAGCTGGAGGACCAAAAATG 5' }^{\prime} \text { 3' CAGCTGGAGGACCAAAAATG 5' }\end{array}$ & 55 \\
\hline
\end{tabular}

Subsequently, to visualize the amplified DNA bands, $2 \mu \mathrm{L}$ of the amplified DNA samples previously mixed with the loading buffer (blue juice) were loaded into the wells of a $\%$ agarose gel with a $100 \mathrm{bp}$ molecular DNA Ladder (10488-058 INVITROGEN). The samples were run in a horizontal electrophoresis chamber at $110 \mathrm{v}$ for 30 minutes. The gels were visualized in the Dolphin View Wealtec photo-reducer. 


\section{Genotyping of cassava DNA samples}

In the SAGA-GT Microsatellite software, a project was created for cassava, detailing the information of each primer such as size, the channel in which they amplify (700-800 $\mathrm{nm})$, the range of band size, the duplexes formed and the position of the cassava samples was located in advance in each position of the gel. First, the acrylamide gel was prepared with $20 \mathrm{ml}$ of K.B. Gel Matrix Plus 6.5\%, $150 \mu \mathrm{l}$ of APS (Ammonium Persulfate) at 10\% and $15 \mu \mathrm{l}$ of Temmed (Tetramethylethylene-diamine at $99 \%$ ), the mixture was placed between the glass plates of the LI-COR 4300 and the comb was placed, after 1 hour of polymerization of the gel, it was placed in the LI-COR 4300 with the 1X TBE (Tris-BorateEDTA) K.B. Plus LI-COR buffer. Subsequently, a pre-run of $25 \mathrm{~min}$ at $1500 \mathrm{~V}$ was performed to focus the laser at 700 and $800 \mathrm{~nm}$. Then, $0.8 \mu \mathrm{L}$ of the amplified products were loaded, previously diluted with Blue Stop Solution LI-COR in a 1:1 ratio and denaturated at $94^{\circ} \mathrm{C}$ for $5 \mathrm{~min}$, and the run was started at $1500 \mathrm{~V}$ for 1 hour and a half. The molecular weight marker IRDye 30-350 bp were used.

\section{Statistical analysis}

The molecular characterization data were obtained using the SAGA GT-SSR version 3.3 software, a reading assistant for the images provided by the LI-COR. The data matrix obtained from SAGA was imported into Excel, where it was purged and saved to continue with the analysis.

\section{Analysis of genetic diversity}

The Power Marker V3.0 program was used for the genetic diversity analysis [44]. The following parameters were obtained: Number of observations, sample size, allele frequency, number of generated genotypes, and number of alleles per locus, total or observed heterozygosity (Ho), genetic diversity or expected heterozygosity $(\mathrm{He})$ and Polymorphism Information Content (PIC).

\section{Cluster Analysis}

For Cluster Analysis, binary data matrix ( 1 and 0 ) was elaborated and analyzed in the Power Marker V3.0 software; a UPGMA tree representation was made to represent the individual relationships between accessions.

\section{Identification of duplicates}

The identification of duplicates was carried out through multilocus microsatellites genotypes and using similarity percentages obtained in the Excel Microsatellites add-on software, which has a value of $100 \%$ for similar individuals.

\section{Variance analysis}

To determine the number of groups with the most significant variability between them, a molecular analysis of variance tested from two to ten groups was used with the Arlequin 2.0 program. 


\section{Results}

\section{Genotyping of SSR markers in LI-CORD}

Homozygous and heterozygous individuals were identified within the cassava collection of 133 accessions. The primer SSRY40 allowed to identify 51 homozygous and 77 heterozygous individuals; with SSRY153 40 homozygous and 93 heterozygous individuals; with SSRY3 72 homozygous and 57 heterozygous individuals; with SSRY151, 19 homozygous and 144 heterozygous; with SSRY68, 64 homozygous and 63 heterozygous; with SSRY31 36 homozygous and 90 heterozygous and with the SSRY100, 69 homozygous and 58 heterozygous individuals were identified.

Table 2. Genetic diversity analysis of 7 cassava SSR markers

\begin{tabular}{ccccccc}
\hline Locus & $\begin{array}{c}\text { Allele } \\
\text { frequency }\end{array}$ & $\begin{array}{c}\text { Obser- } \\
\text { vations } \\
\boldsymbol{n}\end{array}$ & $\begin{array}{c}\text { Alleles } \\
\boldsymbol{n}\end{array}$ & $\begin{array}{c}\text { Genetic Diver- } \\
\text { sity }\end{array}$ & Ho & PIC \\
\hline SSRY40 & 0.64 & 128 & 6 & 0.55 & 0.6 & 0.52 \\
SSRY153 & 0.53 & 133 & 6 & 0.65 & 0.7 & 0.61 \\
SSRY3 & 0.63 & 129 & 6 & 0,56 & 0.44 & 0.52 \\
SSRY151 & 0.21 & 133 & 10 & 0.87 & 0.86 & 0.85 \\
SSRY68 & 0.4 & 127 & 10 & 0.78 & 0.5 & 0.75 \\
SSRY31 & 0.43 & 126 & 8 & 0.72 & 0.71 & 0.69 \\
SSRY100 & 0.42 & 127 & 10 & 0.76 & 0.46 & 0.74 \\
Average & $\mathbf{0 . 4 7}$ & $\mathbf{1 2 9}$ & $\mathbf{8}$ & $\mathbf{0 . 7}$ & $\mathbf{0 . 6 1}$ & $\mathbf{0 . 6 7}$ \\
\hline
\end{tabular}

Table 2 shows the SSRY151 locus, which presented the highest genetic diversity ( 0.87$)$ for the other loci. The loci presented an average genetic diversity value of 0.7 for the seven primers. It is important to note that the primers presented values greater than 0.5 for the PIC. This parameter is essential to determine the index of information provided by these markers within the population. The SSRY151 locus was the most polymorphic with a PIC of 0.85 , while the SSRY40 and SSRY3 loci were the least polymorphic with a PIC of 0.52 . In addition, the SSRY3 locus presented the lowest heterozygosity observed with a value of 0.44 , while on average, for the loci, there was a Ho of 0.61 . Average PIC value was of 0.67 .

\section{Allelic frequency}

The allelic frequency for each primer was determined to analyze the variability of the loci in detail. Allele frequencies and sizes at each locus are detailed in Appendix 1.

\section{Multivariate analysis: Clusters description}

The cluster analysis grouped accessions according to their genotype, allowing a better analysis of the population's genetic diversity. This analysis was performed using the UPGMA method on the main coordinates of the individuals. The dendrogram shown in Figure 1 represents the genetic relationships of the germplasm, where two main groups were identified (G1 and G2). 


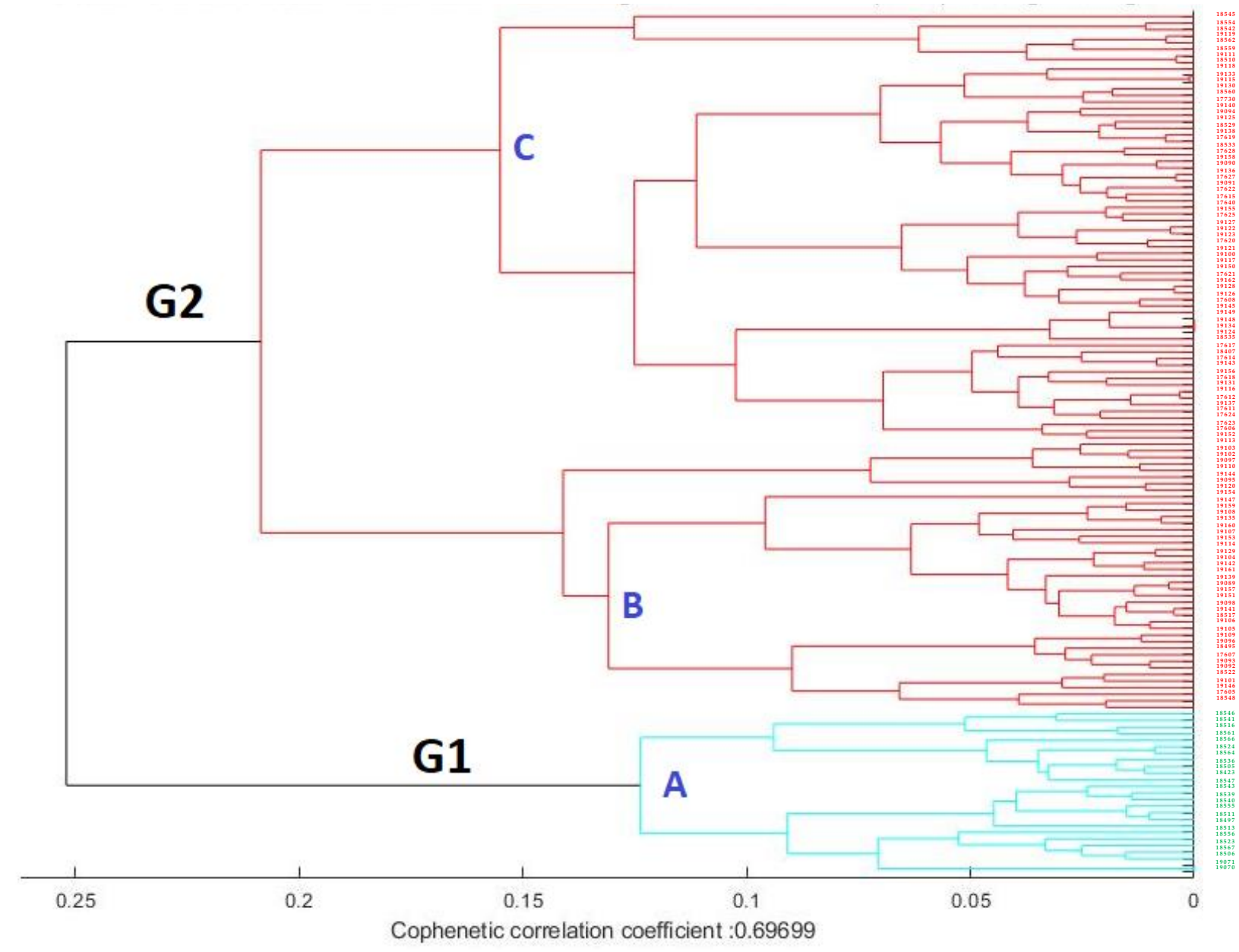

Figure 1. Dendrogram of 133 accessions of Manihot esculenta, indicating two groups based on SSR genotyping. UPGMA and Simple Matching similarity coefficient was used.

\section{Group 1}

This group is formed by subgroup A and contain mostly accessions from Manabí, few accessions from Santo Domingo de Los Tsáchilas, and a minimum number of accessions from Esmeraldas, all these provinces are from the Coast of Ecuador (Appendix 3).

\section{Group 2.}

This group has subgroups $B$ and $C$ and contains all the accessions collected in the Amazonian region, few accessions from Manabí, Santo Domingo de Los Tsáchilas, one accession from Esmeraldas. Subgroup B is made up of accessions from the north-central part of the Amazonian region (Pastaza. Napo, Sucumbíos and Francisco de Orellana) and from the coastal region the accessions of Manabí and Santo Domingo de Los Tsáchilas. In contrast, subgroup C comprises all the accessions collected in Morona Santiago and Zamora Chinchipe; it also contains accessions from Pastaza, Sucumbíos, Napo and Francisco de Orellana, all provinces from the Amazonia. In this group, there are also accessions from the coastal region (Esmeraldas, Manabí, Santo Domingo de los Tsáchilas) and accessions from Tungurahua. The latter province is known as an Andean province; however, the region of the Tungurahua province named "Baños", located in the foothills of the Andes, is known as the door of the Ecuadorian Amazonia toward the province of Pastaza (Appendix 3). 


\section{Analysis of variance}

The Molecular Analysis of Variance (AMOVA) was carried out, grouping the accessions by regions of Ecuador (Coast, Sierra and Amazonia).

The analysis of this grouping is detailed in Table 3.

Table 3. Molecular analysis of variance of 133 accessions from the Ecuadorian cassava collection.

\begin{tabular}{lrrrrr}
\hline \multicolumn{1}{c}{ Source } & df & \multicolumn{1}{c}{ SS } & MS & Est. Var. & \multicolumn{1}{c}{$\%$} \\
\hline Among Populations (Regions) & 2 & 10.605 & 5.302 & 0.049 & $2 \%$ \\
Within Populations & 263 & 665.684 & 2.531 & 2.531 & $98 \%$ \\
\hline Total & 265 & 676.289 & & 2.580 & $100 \%$ \\
\hline
\end{tabular}

Table 3 shows a low percentage of variation among populations or regions (2\%), but most of the variation $(98 \%)$ is due to differentiation among individuals.

\section{Nei Genetic Distance}

The genetic distance of Nei [45] was determined as another parameter to analyze the population genetic structure. For details of the groups' distance, see Appendix 2, where a Nei distance of 0.401 was observed between the G1 and G2 groups.

Appendix 2 shows the genetic distances among the provinces, the greater differentiation are between the provinces of Esmeraldas (Coast) and Tungurahua (Sierra) with a genetic distance of 0.525; Esmeraldas and Morona Santiago (Amazonia) with a genetic distance of 0.518; Santo Domingo de los Tsáchilas (Coast) and Morona Santiago (Amazonia) 0.473; Esmeraldas and Francisco de Orellana (Amazonia) 0.443; Santo Domingo de Tsáchilas and Fco de Orellana 0.414. This data indicates clear differentiation between accessions from the Coast and Sierra and between Amazonia and the Coast of Ecuador.

\section{Identification of duplicates}

The accessions that meet $100 \%$ genetic similarity are three pairs of duplicates (ECU18505, ECU18524); (ECU19070, ECU19071); (ECU19107, ECU19135) and two triplicates (ECU19134, ECU19148, ECU19149); (ECU19115, ECU19125, ECU19118). The duplicates found in the Ecuadorian collection correspond only to $8.8 \%$ of the analyzed accessions.

\section{Discussion}

\section{Genetic diversity of the collection}

The use of microsatellite markers allowed the determination of the genetic diversity of the collection. Furthermore, these markers generated a critical amount of genetic information due to their ability to cover the entire genome, in addition to not presenting intergenic interactions and having simple inheritance [23,46-48,].

Cassava is considered a diploid species, although it is sometimes considered polyploid and possibly an allopolyploid (tetra or hexaploid) [49]. However, only homozygous and heterozygous diploid individuals were found in this study, similarly to Pincay [50]. Our results are consistent with Domínguez et al. [51]; De Carvalho et al. [20]; Ceballos et al. [3]; Ceballos et al. [7] who indicate that cassava is a diploid species. 
In the 133 national cassava accessions, 56 alleles were identified using seven primers. The SSRY151, SSRY68, and SSRY100 loci presented the highest polymorphism index. However, the seven primers presented between 6 and 11 alleles with an average of 8 alleles/loci. Casalla [52], mentioned that a marker is highly polymorphic when identifying more than two alleles per locus. Primer SSRY100 presented the highest number of alleles, similar to Arguello [53], indicating that this primer can be used in future characterizations due to its great discriminating power. Other studies with a similar number of alleles per locus are Beovides et al. [54] from 2 to 10; Arguello [53] range from 3 to 9 or Pincay [50] from 8 to 13.

The observed heterozygosity (Ho) presented an average value of 0.61 with values that vary between 0.5 and 0.86 , similar to those found by Pincay [ 50 These high values confirm that cassava is heterozygous in nature, as in Arguello [53], who also mentions that the asexual reproduction mode of cassava influences the levels of inherited heterozygosity. On the other hand, according to Morillo et al. [55], this high heterozygosity may be related to the allogamous nature of the species. Furthermore, the heterozygosity of cassava was confirmed by other studies such as Alzate et al. [28]. Sosa et al. [56] stated that heterozygosity is one of the critical diversity quantification indices.

\section{Representativeness of the Ecuadorian collection of cassava}

High genetic diversity and a low number of duplicates $(8,8 \%)$ were identified in the Ecuadorian collection. The $100 \%$ duplicates are based mainly on collection-sites closeness, e.g. identical ECU19070 and ECU19071 accessions were collected in Tungurahua in the same place called Río Verde; ECU18505 and ECU18524 were collected in close parishes of the neighboring Coastal provinces of Manabí and Esmeraldas. The triplicate (ECU19134, ECU19148, ECU19149) were collected all in the same province of Pastaza in the Amazonia; and (ECU19115, ECU19125, ECU19118) were collected in the Amazonian province of Sucumbíos. Only the identical ECU19107 and ECU19135 were collected in distant parishes, although from two bordering provinces of Napo and Pastaza in the Amazonia. It is essential to mention that our collection is not wholly duplicated at CIAT, as stated by Tay [4], who indicates that 116 Ecuadorian accessions are conserved at CIAT (CGIAR); however, 134 accessions are considered as only in situ (missing from CGIARs) and not duplicated elsewhere. Cross passport reference between CIAT and INIAP's collections by region determined that CIAT holds $74 \%$ of the Ecuadorian Coastal accessions and only $25 \%$ of our Amazonian accessions; however, INIAP holds only $14 \%$ of the accessions collected in the Sierra from CIAT. Therefore, this Ecuadorian collection filled the gap of missing accessions, especially from the Amazonian region of Ecuador.

\section{Cassava in Ecuadorian farmers' fields}

In the Coastal region, Manabí province is a traditional commercial production area. Mainly smallholders intercrop cassava and other cash crops such as coffee, peanut and maize, among others $[57,58]$. In communities closer to urban centers, cassava is essentially a cash crop, but in more isolated communities, the crop is used mainly for family consumption and animal feed [58]. Industrial cassava byproducts have been produced and exported from Manabí [59], e.g. family farmers in this province have extracted cassava starch for over a hundred years [59,60]. Producer-processer associations occurred years ago [60] and continue today. Our SSR data indicate that accessions from the Manabí province are grouped except for a few materials (Figure 1, Appendix 3). This may be because this province has been supported by several international projects collaborating with INIAP and CIAT [60] which probably increased cassava genetic resources to help the commercial production in the area. Additionally, the genetic distance of Nei (Appendix 2) indicates that there is a difference with other materials from the Coast: Esmeraldas (0.350) 
and Santo Domingo de Los Tsáchilas (0.297), which are provinces that have not had commercial exploitation of yuca like Manabí and consequently less gene flow.

Unlike the Coastal region, where cassava mestizo producers are more inclined to commerce, the cropping shift to self-consumption added to the high cultural importance within indigenous communities in the Amazonia region. Although our collection did not show high genetic diversity within the Amazonian region (Appendix 2), we believed several local landraces are still underrepresented. Currently, they are in the hands of local farmers, especially in indigenous communities of the Amazonian region, e.g. at least five landraces of cassava (lumu) have been reported growing together in one chakra or chagra (swidden garden) at Kichwa communities of Napo [61]. In the chakra Kichwa, similar to other indigenous communities, cassava grows along with other species such as maize, rice, plantain, and beans [62] up to 25 species [63]. Between four and 13 varieties of cassava (kene) are managed by one Waorani family in the chagra de yuca or kewenkore [64]. The Jívaroan indigenous group in Pastaza province, intercrop cassava that occupies most of the cropland of the households [65] and in the same province where Quichua, Shiwiar, and Zapatero indigenous people live reported up to 16 varieties of cassava per household [63]. In this region, cassava presents cultural importance, e.g. Cassava-cropping knowledge is transmitted among women's generations of Kichwas through the delivery of good seeds and practices in the chakra, accompanied by advice [66]. Kichwa mainly uses cassava for self-consumption as food or chicha (fermented cassava beverage); surplus might be directed to the market, especially by mestizos [67]. Then, in situ studies must be conducted to understand the genetic diversity among Amazonian indigenous communities and strengthen the conservation and traditional use of local cassava.

\section{Supplementary Materials: N/A}

Author Contributions: Conceptualization, Á.M.-A. and N.P.; design of the study and supervision. N.P., V.A. and Á.M.-A.; a collection of materials and maintenance of the field experiment N.P. and V.A.; data acquisition V.A.; data curation and statistical analysis V.A., N.P. and Á.M.-A.; interpretation of results and drafting the first manuscript Á.M.A. and V.A.; Writing, review and final editing Á.M.-A. and M.S.; Funding acquisition N.P. All authors have read and agreed to the published version of the manuscript.

Funding: This research was funded by the National Institute of Agricultural Research INIAP [Instituto Nacional de Investigaciones Agropecuarias INIAP], Ecuador; and, CEFA, Comité Europeo para la Formación y la Agricultura.

Institutional Review Board Statement: Not applicable.

Informed Consent Statement: Not applicable.

Data Availability Statement: Not applicable, a review of research from the scientific literature has been used.

Conflicts of Interest: The authors declare no conflict of interest.

Acknowledgements: To the National Secretary of Higher Education, Science, Technology and Innovation (SENESCYT), project PIC 12 INIAP 13, for financing the study. To Dr. Eduardo Morillo and Johanna Buitrón for welcoming Ms. Alulema to training at INIAP's biotechnology laboratory. To CEFA, Comité Europeo para la Formación y la Agricultura, for financially support of the publication. 


\section{References}

1. Schaal, B.A.; Olsen K.M.; Carvalho L.J.C.B. Evolution, Domestication, and Agrobiodiversity in the Tropical Crop Cassava. In Darwin's harvest, new approaches to the origins, evolution and conservation of crops, Motley, T., Zerega, N., Cross, H., Eds.; Columbia University Press. New York, USA, 2006; 269-284. https://doi.org/10.7312/motl13316

2. Bikram, F.; Bernd, F.; Dal-Hoe, K.; Wanlong, L. Crop species origins, the impact of domestication and the potential of wide hybridization for crop improvement. In Sustaining Global Food Security: The nexus of science and policy, Zeigler, R.S., Ed., CSIRO Publishing, Clayton, Australia, 2019; 15-35.

3. Ceballos, H.; Okogbenin, E.; Pérez, J.C.; López-Valle, L.A.B.; Debouck, D. Cassava, Chapter 2. In Root and Tuber Crops, Handbook of Plant Breeding 7, Bradshaw, J.E., Ed., Springer-Verlag, New York, USA, 2010; 53-95. https://doi.org/10.1007/978-0-387-927657_2.

4. Tay, D. Tropical and Subtropical Root and Tuber Crops. Chapter 12. In Conservation of Tropical Plant Species, Normah, M.N., Chin, H.F., Reed, B.M., Eds., Springer-Verlag, New York, USA, 2013; 249-292. https://doi.org/10.1007/978-1-4614-3776-5_12,

5. Henry, G.; Hershey, C. Cassava in South America and the Caribbean. Chapter 2. In Cassava: Biology, production and utilization. Hillocks, R.J., Thresh, Eds., CABI Publishing, Wallingford, England, UK, 2001 ; 17-40. https://doi.org/10.1079/9780851995243.0017

6. Parmar, A.; Sturm, B.; Hensel, O. Crops that feed the world: Production and improvement of cassava for food, feed, and industrial uses. Food Sec 2017 9, 907-927. https://doi.org/10.1007/s12571-017-0717-8

7. Ceballos, H.; Kulakow, P.; Hershey, C. Cassava Breeding: Current Status, Bottlenecks and the Potential of Biotechnology Tools. Trop Plant Biol 2012 5, 73-87 https://doi.org/10.1007/s12042-012-9094-9

8. Katz, E.; López, C.L.; Fleury, M.; Miller, R.P.; Payê, V.; Dias, T.; Silva, F.; Oliveira, Z.; Moreira, E. No greens in the forest? Note on the limited consumption of greens in the Amazon. Acta Soc Bot Pol 2012 81(4), 283-293 https://doi.org/10.5586/asbp.2012.048

9. Olsen, K.M.; Schaal, B.A. Microsatellite variation in cassava (Manihot esculenta, Euphorbiaceae) and its wild relatives: further evidence for a southern Amazonian origin of domestication. Am J Bot 2001 88(1), 131-142. https://doi.org/10.2307/2657133

10. Ferguson, M.E.; Shah, T.; Kulakow, P.; Ceballos, H. A global overview of cassava genetic diversity. PLOS ONE 2019 14(11), e0224763. https://doi.org/10.1371/journal.pone.0224763

11. Allem, A.C. The origins and taxonomy of Cassava. Chapter 1. In Cassava: Biology, production and utilization. Hillocks, R.J., Thresh, Eds., CABI Publishing, Wallingford, England, UK, 2001; 1-16. https://doi.org/10.1079/9780851995243.0001

12. Nassar, N.M. Conservation of the genetic resources of cassava (Manihot esculenta) determination of wild species localities with emphasis on probable origin. Econ Bot 2008 32, 311-320. https://doi.org/10.1007/BF02864705

13. Fregene, M.A.; Vargas, J.; Ikea, J.; Angel, F.; Tohme, J.; Asiedu, R.A.; Akoroda, M.O.; Roca, W.M. Variability of chloroplast DNA and nuclear ribosomal DNA in cassava (Manihot esculenta Crantz) and its wild relatives. Theor Appl Genet 1994 89, $719-727$. https://doi.org/10.1007/BF00223711

14. Allem, A.C. The closest wild relatives of cassava (Manihot esculenta Crantz). Euphytica 1999 107, $123-133$. https://doi.org/10.1023/A:1026422229054

15. Olsen, K.M.; Schaal, B.A. Evidence on the origin of cassava: phylogeography of Manihot esculenta. PNAS USA 1999 96(10), 55865591. https://doi.org/10.1073/pnas.96.10.5586

16. Olsen, K.M. SNPs, SSRs and inferences on cassava's origin. Plant Mol Biol 2004 56, 517-526. https://doi.org/10.1007/s11103-0045043-9

17. Bredeson, J.V.; Lyons, J.B.; Prochnik, S.E.; Wu, G.A.; Ha, C.M. Edsinger-Gonzales, E.; Grimwood, J.; Schmutz, J.; Rabbi, I.Y.; Egesi, C.; Nauluvula, P.; Lebot, V.; Ndunguru, J.; Mkamilo, G.; Bart, R.S.; Setter, T.L.; Gleadow, R.M.; Kulakow, P.; Ferguson, M.E.; Rounsley, S.; Rokhsar, D.S. Sequencing wild and cultivated cassava and related species reveals extensive interspecific hybridization and genetic diversity. Nat Biotechnol 2016 34(5) 562-570. https://doi.org/10.1038/nbt.3535

18. Allem, A.; Mendes, R.; Salomão, A.; Burle, M.L. The primary gene pool of cassava (Manihot esculenta Crantz subspecies esculenta, Euphorbiaceae), Euphytica 2001, 120, 127-132. https://doi.org/10.1023/A:1017544813397

19. Léotard, G.; Duputié, A.; Kjellberg, F. Phylogeography and the origin of cassava: new insights from the northern rim of the Amazonian basin, Mol Phylogenet Evol, 2009, 53, 329-334. https://doi.org/10.1016/j.ympev.2009.05.003

20. De Carvalho, R.; Guerra, M. Cytogenetics of Manihot esculenta Crantz (cassava) and eight related species. Hereditas, 2002, 136, 159-168. https://doi.org/10.1034/j.1601-5223.2002.1360212.x

21. Zaldivar, M.E.; Rocha, O.J.; Aguilar, G.; Castro, L.; Castro, E.; Barrantes, R. Genetic variation of cassava (Manihot esculenta Crantz) cultivated by Chibchan amerindians of Costa Rica. Econ Bot, 2004, 58(2), 204-213. https://doi.org/10.1663/00130001(2004)058[0204:GVOCME]2.0.CO;2

22. Asante, I.K.; Offei, S.K. RAPD-based genetic diversity study of fifty cassava (Manihot esculenta Crantz) genotypes. Euphytica 2003, 131, 113-119. https://doi.org/10.1023/A:1023056313776

23. Demey, J.R.; Zambrano, A.Y.; Fuenmayor, F.; Segovia, Y.V. Relación entre caracterizaciones molecular y morfológica en una colección de yuca. Interciencia, 2003, 28(12), 684-689. http://www.redalyc.org/articulo.oa?id=33908702

24. Branco-Carvalho, L.J.C.; Batista de Souza, C.R.; Mattos Cascardo, J.C. de; Valle Agostini, M.A.; Bloch Jr., C. Celebrating diversity in storage root of cassava (Manihot esculenta Crantz). CIAT library, Cali Colombia, 2001, 1p. http://ciat-library.ciat.cgiar.org/articulos_ciat/cbn/Posters-PDF/PS-2/L_Carvalho_Celebrating_AAA.pdf

25. Carvalho, L.J.C.B.; Schaal, B.A. Assessing genetic diversity in the cassava (Manihot esculenta Crantz) germplasm collection in Brazil using PCR-based markers. Euphytica 2001, 120, 133-142. https://doi.org/10.1023/A:1017548930235 
26. Elias, M.; Mühlen, G.S.; McKey, D.; Roa, A.C.; Tohme, J. Genetic diversity of traditional South American Landraces of Cassava (Manihot esculenta Crantz): an analysis using microsatellites. Econ Bot 2004, 58, 242-256. https://doi.org/10.1663/00130001(2004)058[0242:GDOTSA]2.0.CO;2

27. Ferreira Moura, E.F.; Reis Sousa, N.R.; Fecuri Moura, M.F.; Costa Dias, M.; Diel Souza, E.; Farias Neto, J.T. de; Sampaio, J.E. . Molecular characterization of accessions of a rare genetic resource: sugary cassava (Manihot esculenta Crantz) from Brazilian Amazon, Genet Resour Crop Evol 2016, 63, 583-593. https://doi.org/10.1007/s10722-016-0378-z

28. Alzate, A.M.; Vallejo Cabrera, F.A.; Ceballos Lascano, H.; Pérez, J.C.; Fregene, M. Variabilidad genética de la yuca cultivada por pequeños agricultores de la región Caribe de Colombia. Acta Agron 2010, 59(4), 385-393. https://revistas.unal.edu.co/index.php/acta_agronomica/article/view/20120/21193

29. Karim, K.Y.; Ifie, B.; Dzidzienyo, D.; Danquah, E.Y.; Blay, E.T.; Whyte, J.B.A.; Kulakow, P.; Rabbi, I., Parkes, E.; Omoigui, L.; Norman, P.E.; Iluebbey, P. Genetic characterization of cassava (Manihot esculenta Crantz) genotypes using agro-morphological and single nucleotide polymorphism markers. Physiol Mol Biol Plants 2020, 26, 317-330. https://doi.org/10.1007/s12298-01900740-x

30. Elias, M.; Panaud, O.; Robert, T. Assessment of genetic variability in a traditional cassava (Manihot esculenta Crantz) farming system, using AFLP markers. Heredity 2000, 85, 219-230. https://doi.org/10.1046/j.1365-2540.2000.00749.x

31. Kawuki, R.S.; Ferguson, M.; Labuschagne, M.; Herselman, L. Identification, characterisation and application of single nucleotide polymorphisms for diversity assessment in cassava (Manihot esculenta Crantz). Mol Breed 2009, 23, 669-684. https://doi.org/10.1007/s11032-009-9264-0

32. Bhattacharjee, R.; Ferguson, M.; Gedil, M.; Dumet, D.; Ingelbrecht, I. Field collection, preservation and large scale DNA extraction procedures for cassava (Manihot esculenta Crantz.). Afr J Biotechnol 2009, 8(15), 3424-3430. Available online at http://www.academicjournals.org/AJB ISSN 1684-5315 (c) 2009 Academic Journals

33. Roa, A.; Maya, M.; Duque, M.; Tohme, J. AFLP analysis of relationships among cassava and other Manihot species. Theor Appl Genet 1997, 95, 741-750. https://doi.org/10.1007/s001220050620

34. Roa A.C., Chavarriaga-Aguirre P., Duque M. C., Maya M. M., Bonierbale M. W., Iglesias C., Tohme J. Cross-species amplification of cassava (Manihot esculenta) (Euphorbiaceae) microsatellites: allelic polymorphism and degree of relationship. Am J Bot 2000, 87(11), 1647-1655. https://doi.org/10.2307/2656741.

35. Xia, L.; Peng, K.; Yang, S.; Wenzl, P.; Vicente, M.C. de; Fregene, M.; Kilian, A. DArT for high-throughput genotyping of Cassava (Manihot esculenta) and its wild relatives. Theor Appl Genet 2005, 110, 1092-1098. https://doi.org/10.1007/s00122-005-1937-4

36. Raji, A.A.; Anderson, J.V.; Kolade, O.A.; Ugwu, C.D.; Dixon, A.G.O.; Ingelbrecht, I.L. Gene-based microsatellites for cassava (Manihot esculenta Crantz): prevalence, polymorphisms, and cross-taxa utility. BMC Plant Biol 2009,9 , 118. https://doi.org/10.1186/1471-2229-9-118

37. de Bang, T.C.; Raji, A.A.; Ingelbrecht, I.L. A Multiplex Microsatellite Marker Kit for Diversity Assessment of Large Cassava (Manihot esculenta Crantz) Germplasm Collections. Plant Mol Biol Rep 2011, 29, 655-662. https://doi.org/10.1007/s11105-010-0273$\underline{2}$

38. Chavarriaga-Aguirre, P.; Maya, M.M.; Tohme, J.; Duque, M.C.; Iglesias, C.; Bonierbale, M.W.; Kresovich, S.; Kochert, G. Using microsatellites, isozymes and AFLPs to evaluate genetic diversity and redundancy in the cassava core collection and to assess the usefulness of DNA-based markers to maintain germplasm collections. Mol Breed 1999, 5, $263-273$. https://doi.org/10.1023/A:1009627231450

39. Monteros-Altamirano, Á.; Tapia, C.; Paredes, N.; Alulema, V.; Tacán, M.; Roura, A.; Lima, L.; Sørensen, M. Morphological and Ecogeographic Study of the Diversity of Cassava (Manihot esculenta Crantz) in Ecuador. Agronomy 2021, 11(9), 1844; https://doi.org/10.3390/agronomy11091844

40. Ferreira, M.E.; Grattapaglia, D. Introducción al uso de marcadores moleculares en el análisis genético, $3^{\text {rd }}$ ed. EMBRAPA- CENARGEN Brasília, Brazil, 1998. 220p.

41. Morillo, E.; Miño Castro, G. Marcadores Moleculares en Biotecnología Agrícola: Manual de procedimientos y técnicas en INIAP [Instituto Nacional de Investigaciones Agropecuarias]. Quito, Ecuador, 2011. 121p. https://www.researchgate.net/publication/258803041_MANUAL Biologia Molecular INIAP

42. Chavarriaga-Aguirre, P.; Maya, M.; Bonierbale, M.; Kresovich, S.; Fregene, M.A.; Tohme, J.; Kochert, G. Microsatellites in Cassava (Manihot esculenta Crantz): discovery, inheritance and variability. Theor Appl Genet 1998, 97, $493-501$. https://doi.org/10.1007/s001220050922

43. Mba, R.; Stephenson, P.; Edwards, K.; Melzer, S.; Mkumbira, J.; Gullberg, U.; Apel, K.; Gale, M.; Tohme, J.; Fregene, M. Simple sequence repeat (SSR) markers survey of the cassava (Manihot esculenta Crantz) genome: towards an SSR-based molecular genetic map of cassava. Theor Appl Genet 2001, 102(1), 21-31. https://doi.org/10.1007/s001220051614

44. Liu, K.; Muse, S. Power marker: Integrated analysis environment for genetic marker data. Bioinformatics 2005, 21(9), 2128-2129. https://doi.org/10.1093/bioinformatics/bti282

45. Nei, M. Genetic Distance between Populations. Am Nat 1972, 106(949), 283-292. http://www.jstor.org/stable/2459777.

46. Avise, J.C. Molecular Markers, Natural History and Evolution, $2^{\text {nd }}$ ed. Sinauer Associates, Inc. Publishers, Sunderland, Massachusetts, USA, 2004. 684p. ISBN-10: 0878930418

47. Wilson, A.; Sarich, V.; Maxson, L. The importance of gene rearrangement in evolution: evidence from studies of rates of chromosomal, protein and anatomical evolution. PNAS 1974, 71, 3028-3030. 10.1073/pnas.71.8.3028 
48. Hillis, D.; Wiens, J. Molecules versus morphology in systematics. In Phylogenetic analysis of morphological data, Wiens, J. Ed.; Smithsonian Institution Press, Washington, USA, 2000; pp 1-19.

49. Ceballos, H.; De la Cruz, G. Taxonomía y morfología de yucca. In La Yuca en el Tercer Milenio. Sistema Moderno de Producción, Procesamiento, Utilización y Comercialización, Ospina, B., Ceballos, H. Eds.; Centro Internacional de Agricultura Tropical, Cali, Colombia; 2002. pp. 17-33. https://cgspace.cgiar.org/bitstream/handle/10568/55239/capitulo02.pdf?sequence=2\&isAllowed=y

50. Pincay Anchundia, L.M. Caracterización agronómica, morfológica y molecular del banco de germoplasma de yuca (Manihot esculenta Crantz) de la estación experimental Portoviejo del INIAP. Ing. Agr. Thesis, Universidad técnica de Manabí, Portoviejo, Ecuador. 2010. 110 p. https://repositorio.iniap.gob.ec/bitstream/41000/4111/1/iniapeeptp647c.pdf

51. Domínguez, O.; Ceballos, L.; Fuentes, C.; Fuentes de Piedrahita, C.L. Morfología de la planta de yuca. In Yuca: Investigación, producción y utilización, Domínguez M., C.E. Ed.; Centro Internacional de Agricultura Tropical (CIAT), Programa de Yuca; Programa de las Naciones Unidas para el Desarrollo (PNUD), Cali, Colombia; 1983. pp. 29-49. http://ciat-library.ciat.cgiar.org/Articulos_Ciat/Digital/SB211.C4_Y85_Yuca_Investigaci\%C3\%B3n,_producci\%C3\%B3n_y_utilizaci\%C3\%B3n.pdf\#page=42

52. Casalla, R. Medición de la distancia genética en grupos de camarón blanco Liptopenaeus vannamei en la costa ecuatoriana. MSc Thesis, Escuela Superior Politécnica del Litoral, Guayaquil, Ecuador; 2003. 83 p. https://node1.123dok.com/dt02pdf/123dok_es/002/511/ 2511142.pdf.pdf?X-Amz-Content-Sha256=UNSIGNED-PAYLOAD\&X-Amz-Algorithm=AWS4-HMAC-SHA256\&X-Amz-Credential=7PKKQ3DUV8RG19BL\%2F20211023\%2F\%2Fs3\%2Faws4_request\&X-Amz-Date=20211023T095152Z\&X-Amz-SignedHeaders=host\&X-Amz-Expires=600\&X-Amz-Signaure=9a90fef5a48c09b7a8bcfb947e114edebebb33deb642b8b8f253dee115c7b 089

53. Argüello Diaz, J.N. Caracterización molecular de 52 accesiones de yuca (Manihot esculenta Crantz) usando nueve marcadores tipo SSR. CNIAB-INTA, Nicaragua. Ing. Thesis, Universidad Nacional Agraria, Managua, Nicaragua; 2012.52 p. https://repositorio.una.edu.ni/2165/1/tnf30a694y.pdf

54. Beovides, Y.; Fregene, M.; Alves, A.; Gutiérrez, J.; Buitrago, C.; Marin, A.; Milán, M.; Rodríguez, J.; Guerra, D.; Toledo, H.; Roca, O.; Albert, J.; Oliva, M. Análisis de diversidad genética mediante microsatélites (SSR) en cultivares del germoplasma cubano de yuca. Biotecnol Veg 2006, 6(1), 9-14. https://revista.ibp.co.cu/index.php/BV/article/view/390/359

55. Morillo, A., Morillo, Y. \& Ceballos, H. (2013). Identificación de QTLs para carotenos en el genoma de yuca, (Manihot esculenta Crantz), y validación en poblaciones S1. Acta agronómica, 62(3), 196-206.

56. Sosa, P., Batista, F.; González, M.; Bouza, N. La Conservación Genética de las Especies Amenazadas. In Biología de la Conservación de Plantas Amenazadas: Técnicas de Diagnóstico del Estado de Conservación, Bañares, A. Ed.; Organismo Autónomo de Parques Nacionales, Madrid, Spain; 2002. pp. 133-160. https://accedacris.ulpgc.es/bitstream/10553/1285/1/82.pdf

57. Mack, M. Income and nutrition in smallholder farm households in Manabi province, Ecuador. PhD Thesis. University of Arizona, Tucson, USA; 1993. 294 p.

58. Leonard, W.R.; Dewalt, K.M.; Uquillas, J.E.; Dewalt, B.R. Diet and nutritional status among cassava producing agriculturalists of coastal Ecuador. Ecol Food Nutr 1994, 32(3-4), 113-127. https://doi.org/10.1080/03670244.1994.9991393

59. Eguez, C. Cassava Starch and Flour in Ecuador: Its commercialization and use. Chapter 7. In Cassava flour and starch: progress in research and development, Chapter 38; Dufour, D., O'Brien, G.M., Best, R. Eds.; CIAT. Publication No. 271. Cali, Colombia; 1996; pp. 333-357. https://books.google.com.ec/books?hl=en\&lr=\&id=Ns3JgEziPeIC\&oi=fnd\&pg=PA333\&dq=Ospina+1996,+cassava, +ecuador\&ots=ZNWc7xGNZb\&sig=E-t0ZxLwidczgxYzKUyWq3a4RL8\&redir_esc=y\#v=onepage\&q=Ospina $\% 201996 \% 2 C \%$ 20cassava $\% 2 \mathrm{C} \% 20$ ecuador\&f=false

60. Ospina, B.; Poats, S.; Henry G. 1996. Integrated cassava research and development projects in Colombia, Ecuador and Brazil: an overview of CIAT's experience. In Cassava flour and starch: progress in research and development, Chapter 38; Dufour, D., O'Brien, G.M., Best, R. Eds.; CIAT. Publication No. 271. Cali, Colombia; 1996; pp. 333-357. https://books.google.com.ec/ books?hl=en\&lr=\&id=Ns3JgEziPeIC\&oi=fnd\&pg=PA333\&dq=Ospina+1996,+cassava,+ecuador\&ots=ZNWc7xGNZb\&sig=Et0ZxLwidczgxYzKUyWq3a4RL8\&redir_esc=y\#v=onepage\&q=Ospina\%201996\%2C\%20cassava\%2C\%20ecuador\&f=false

61. Peñuela-Mora, C.; Schwarz, A.; Monteros-Altamirano, A.; Zurita-Benavidez, M.; Cayapa, R.; Romero, N. Guía de la Agrobiodiversidad: Tres comunidades kichwa: Atacapi, Alto Tena y Pumayacu. Universidad Regional Amazónica IKIAM, Tena, Ecuador; 2016 130 p. ISBN: 978-9942-8638-1-2

62. Arevalo-Vizcaino, V.; Vera-Vélez, R.; Grijalva-Olmedo, J. Mejoramiento de chakras, una alternativa de Sistema Integrado para la Gestión Sostenible de Bosques en comunidades nativas de la Amazonía Ecuatoriana. 6to Congreso Forestal Español. Sociedad Española de Ciencias Forestales, Vitoria-Gasteiz, Spain; 2013. https://www.researchgate.net/publication/320944642

63. Garí, J.A. Biodiversity and indigenous agroecology in amazonia: The indigenous peoples of Pastaza. Etnoecológica 1999, 5(7), 21-37. http://etnoecologia.uv.mx/Etnoecologica/Etnoecologica_vol5_n7/Articulo\%20Gari.pdf

64. Zurita, G. Cultivando las plantas y la sociedad waorani. Bol Mus Para. Emílio Goeldi Cienc Hum Belém 2017, 12(2), 495-516. https://doi.org/10.1590/1981.81222017000200013

65. López, S.; Sierra, R. A resource demand model of indigenous production: The Jivaroan cultivation systems of Western Amazonia. Agric Syst 2011, 104(3), 246-257. https://doi.org/10.1016/j.agsy.2010.10.003

66. GIZ. La Chakra Kichwa. Criterios para la conservación y fomento de un sistema de producción sostenible en la Asociación KALLARI y sus organizaciones socias. Fascículo 7. GIZ, GESOREN-GIZ, KALLARI; Bonn, Germany; 2013; 24 p. https://docplayer.es/20560435-La-chakra-kichwa-criterios-para-la-conservacion-y-fomento-de-un-sistema-de-produccion-sostenible-en-laasociacion-kallari-y-sus-organizaciones-socias.html

67. Grijalva, J.; Limongi, R.; Arevalo, V.; Vera, R.; Quiroz, J.; Yumbo, A.; Jara, F.; Sighcha, F.; Riofrio, J.; Cerda, A. Mejoramiento de Chakras. Una alternativa de sistema integrado con cacao, cultivos anuales y árboles en el alto Napo. Programa Nacional de 
Forestería del INIAP. Editorial Nina Comunicaciones. Quito - Ecuador. Boletín Divulgativo 2011, 372, 1-28. https://repositorio.iniap.gob.ec/bitstream/41000/325/4/iniapscbd372.pdf

Appendix 1. Alleles found with their frequencies and sizes in 133 accessions from the cassava collection.

\begin{tabular}{|c|c|c|c|c|c|c|c|}
\hline Locus & $\begin{array}{l}\text { Al- } \\
\text { lele }\end{array}$ & $\begin{array}{c}\text { Frecuency } \\
\text { G1 }\end{array}$ & $\begin{array}{c}\text { Frecuency } \\
\text { G2 }\end{array}$ & Locus & $\begin{array}{l}\text { Al- } \\
\text { lele }\end{array}$ & $\begin{array}{c}\text { Frecuency } \\
\text { G1 }\end{array}$ & $\begin{array}{c}\text { Frecuency } \\
\text { G2 }\end{array}$ \\
\hline \multirow{6}{*}{ SSRY40 } & 220 & 0.021 & 0.000 & \multirow{10}{*}{ SSRY68 } & 248 & 0.063 & 0.110 \\
\hline & 224 & 0.688 & 0.583 & & 250 & 0.042 & 0.440 \\
\hline & 228 & 0.000 & 0.161 & & 254 & 0.000 & 0.110 \\
\hline & 230 & 0.083 & 0.078 & & 256 & 0.000 & 0.041 \\
\hline & 234 & 0.000 & 0.018 & & 258 & 0.063 & 0.014 \\
\hline & 236 & 0.125 & 0.106 & & 260 & 0.000 & 0.018 \\
\hline \multirow{6}{*}{ SSRY153 } & 96 & 0.500 & 0.518 & & 262 & 0.021 & 0.005 \\
\hline & 102 & 0.167 & 0.018 & & 264 & 0.104 & 0.055 \\
\hline & 104 & 0.083 & 0.005 & & 266 & 0.458 & 0.096 \\
\hline & 106 & 0.000 & 0.087 & & 288 & 0.167 & 0.046 \\
\hline & 114 & 0.063 & 0.188 & \multirow{8}{*}{ SSRY31 } & 160 & 0.500 & 0.381 \\
\hline & 116 & 0.104 & 0.174 & & 162 & 0.000 & 0.009 \\
\hline \multirow{6}{*}{ SSRY3 } & 236 & 0.438 & 0.014 & & 166 & 0.042 & 0.037 \\
\hline & 240 & 0.229 & 0.032 & & 172 & 0.000 & 0.014 \\
\hline & 242 & 0.146 & 0.697 & & 176 & 0 & 0.055 \\
\hline & 244 & 0.042 & 0.000 & & 180 & 0.125 & 0.037 \\
\hline & 248 & 0.021 & 0.005 & & 188 & 0.021 & 0.183 \\
\hline & 250 & 0.000 & 0.216 & & 192 & 0.313 & 0.193 \\
\hline \multirow{10}{*}{ SSRY151 } & 174 & 0.000 & 0.009 & \multirow{10}{*}{ SSRY100 } & 192 & 0.042 & 0.041 \\
\hline & 178 & 0.000 & 0.028 & & 196 & 0.021 & 0.018 \\
\hline & 180 & 0.000 & 0.156 & & 200 & 0.000 & 0.188 \\
\hline & 182 & 0.042 & 0.138 & & 206 & 0.000 & 0.037 \\
\hline & 184 & 0.313 & 0.041 & & 210 & 0.063 & 0.037 \\
\hline & 186 & 0.021 & 0.073 & & 212 & 0.646 & 0.339 \\
\hline & 188 & 0.021 & 0.092 & & 214 & 0.083 & 0.156 \\
\hline & 192 & 0.396 & 0.023 & & 220 & 0.00 & 0.014 \\
\hline & 210 & 0.083 & 0.234 & & 240 & 0.042 & 0.060 \\
\hline & 216 & 0.08333 & 0.188 & & 242 & 0.021 & 0.046 \\
\hline
\end{tabular}

Note: alleles with less frequency are indicated in blue and alleles with greater frequency in red. 
Appendix 2. Nei genetic distance matrix between 10 provinces (Coast, Sierra and Amazonia) and 2 countries of origin of the cassava collection accessions.

\begin{tabular}{|c|c|c|c|c|c|c|c|c|c|c|}
\hline & \multicolumn{3}{|c|}{ COAST } & \multicolumn{6}{|c|}{ AMAZONIA } & \multirow{2}{*}{$\frac{\text { SIERRA }}{\text { TU }}$} \\
\hline & ESM & MAN & SD & SUC & FO & NA & PA & MS & $\mathrm{ZC}$ & \\
\hline ESM & 0.000 & & & & & & & & & \\
\hline MAN & 0.350 & 0.000 & & & & & & & & \\
\hline SD & 0.342 & 0.297 & 0.000 & & & & & & & \\
\hline SUC & 0.314 & 0.083 & 0.222 & 0.000 & & & & & & \\
\hline FO & 0.443 & 0.119 & 0.414 & 0.132 & 0.000 & & & & & \\
\hline NA & 0.379 & 0.123 & 0.362 & 0.101 & 0.168 & 0.000 & & & & \\
\hline PA & 0.333 & 0.103 & 0.295 & 0.116 & 0.143 & 0.114 & 0.000 & & & \\
\hline MS & 0.518 & 0.213 & 0.473 & 0.192 & 0.265 & 0.166 & 0.161 & 0.000 & & \\
\hline $\mathrm{ZC}$ & 0.415 & 0.183 & 0.320 & 0.157 & 0.251 & 0.159 & 0.184 & 0.311 & 0.000 & \\
\hline TU & 0.525 & 0.175 & 0.384 & 0.126 & 0.245 & 0.151 & 0.221 & 0.241 & 0.165 & 0.000 \\
\hline
\end{tabular}

ESM: Esmeraldas, MAN: Manabí, SD: Santo Domingo de los Tsáchilas, SUC: Sucumbíos, FO: Francisco de Orellana, NA: Napo, PA: Pastaza, MS: Morona Santiago, ZC: Zamora Chinchipe, TU: Tungurahua.

Appendix 3. Grouping of 133 Ecuadorian accessions of cassava by using SSR markers.

\begin{tabular}{|c|c|c|c|c|c|c|c|c|c|}
\hline \multicolumn{2}{|c|}{ GROUP 1} & \multicolumn{8}{|c|}{ GROUP 2} \\
\hline ACC & PROVINCE & ACC & PROVINCE & $\mathrm{ACC}$ & PROVINCE & ACC & PROVINCE & ACC & PROVINCE \\
\hline ECU-18423 & Manabí & ECU-17603 & Pastaza & ECU-18554 & Manabí & ECU-19117 & Sucumbíos & ECU-19150 & $\begin{array}{l}\text { Francisco de } \\
\text { Orellana }\end{array}$ \\
\hline ECU-18497 & Manabí & ECU-17604 & Pastaza & ECU-18559 & Manabí & ECU-19118 & Sucumbíos & ECU-19151 & $\begin{array}{l}\text { Francisco de } \\
\text { Orellana }\end{array}$ \\
\hline ECU-18505 & Manabí & ECU-17605 & Pastaza & ECU-18560 & Manabí & ECU-19119 & Sucumbíos & ECU-19152 & $\begin{array}{l}\text { Francisco de } \\
\text { Orellana }\end{array}$ \\
\hline ECU-18506 & Manabí & ECU-17606 & Pastaza & ECU-18562 & Manabí & ECU-19120 & Sucumbíos & ECU-19153 & $\begin{array}{l}\text { Francisco de } \\
\text { Orellana }\end{array}$ \\
\hline
\end{tabular}




\begin{tabular}{|c|c|c|c|c|c|c|c|c|c|}
\hline ECU-18511 & $\begin{array}{l}\text { Santo Do- } \\
\text { mingo de los } \\
\text { Tsáchilas }\end{array}$ & ECU-17607 & Pastaza & ECU-19070 & Tunguragua & ECU-19121 & Sucumbíos & ECU-19154 & $\begin{array}{l}\text { Francisco de } \\
\text { Orellana }\end{array}$ \\
\hline ECU-18513 & $\begin{array}{l}\text { Santo Do- } \\
\text { mingo de los } \\
\text { Tsáchilas }\end{array}$ & ECU-17608 & Sucumbíos & ECU-19071 & Tunguragua & ECU-19122 & Sucumbíos & ECU-19155 & $\begin{array}{l}\text { Francisco de } \\
\text { Orellana }\end{array}$ \\
\hline ECU-18516 & $\begin{array}{l}\text { Santo Do- } \\
\text { mingo de los } \\
\text { Tsáchilas }\end{array}$ & ECU-17611 & Sucumbíos & ECU-19089 & Napo & ECU-19123 & Sucumbíos & ECU-19156 & $\begin{array}{l}\text { Francisco de } \\
\text { Orellana }\end{array}$ \\
\hline ECU-18523 & $\begin{array}{l}\text { Santo Do- } \\
\text { mingo de los } \\
\text { Tsáchilas }\end{array}$ & ECU-17612 & $\begin{array}{l}\text { Zamora } \\
\text { Chinchipe }\end{array}$ & ECU-19090 & Napo & ECU-19124 & Sucumbíos & ECU-19157 & $\begin{array}{l}\text { Francisco de } \\
\text { Orellana }\end{array}$ \\
\hline ECU-18524 & Esmeraldas & ECU-17614 & $\begin{array}{l}\text { Zamora } \\
\text { Chinchipe }\end{array}$ & ECU-19091 & Napo & ECU-19125 & Sucumbíos & ECU-19158 & $\begin{array}{l}\text { Francisco de } \\
\text { Orellana }\end{array}$ \\
\hline ECU-18536 & $\begin{array}{l}\text { Santo Do- } \\
\text { mingo de los } \\
\text { Tsáchilas }\end{array}$ & ECU-17615 & $\begin{array}{l}\text { Zamora } \\
\text { Chinchipe }\end{array}$ & ECU-19092 & Napo & ECU-19126 & Sucumbíos & ECU-19159 & $\begin{array}{l}\text { Francisco de } \\
\text { Orellana }\end{array}$ \\
\hline ECU-18539 & Esmeraldas & ECU-17617 & $\begin{array}{l}\text { Zamora } \\
\text { Chinchipe }\end{array}$ & ECU-19093 & Napo & ECU-19127 & Sucumbíos & ECU-19160 & $\begin{array}{l}\text { Francisco de } \\
\text { Orellana }\end{array}$ \\
\hline ECU-18540 & Manabí & ECU-17618 & $\begin{array}{l}\text { Zamora } \\
\text { Chinchipe }\end{array}$ & ECU-19094 & Napo & ECU-19128 & Sucumbíos & ECU-19161 & $\begin{array}{l}\text { Francisco de } \\
\text { Orellana }\end{array}$ \\
\hline ECU-18541 & Manabí & ECU-17619 & $\begin{array}{l}\text { Zamora } \\
\text { Chinchipe }\end{array}$ & ECU-19095 & Napo & ECU-19129 & Sucumbíos & ECU-19162 & $\begin{array}{l}\text { Francisco de } \\
\text { Orellana }\end{array}$ \\
\hline ECU-18543 & Manabí & ECU-17620 & $\begin{array}{l}\text { Zamora } \\
\text { Chinchipe }\end{array}$ & ECU-19096 & Napo & ECU-19130 & Sucumbíos & & \\
\hline ECU-18545 & Manabí & ECU-17621 & $\begin{array}{l}\text { Morona Santi- } \\
\text { ago }\end{array}$ & ECU-19097 & Napo & ECU-19131 & Sucumbíos & & \\
\hline ECU-18546 & Manabí & ECU-17622 & $\begin{array}{l}\text { Morona Santi- } \\
\text { ago }\end{array}$ & ECU-19098 & Napo & ECU-19133 & Sucumbíos & & \\
\hline ECU-18547 & Manabí & ECU-17623 & $\begin{array}{l}\text { Morona Santi- } \\
\text { ago }\end{array}$ & ECU-19100 & Napo & ECU-19134 & Pastaza & & \\
\hline ECU-18548 & Manabí & ECU-17624 & $\begin{array}{l}\text { Morona Santi- } \\
\text { ago }\end{array}$ & ECU-19101 & Napo & ECU-19135 & Pastaza & & \\
\hline ECU-18555 & Manabí & ECU-17625 & $\begin{array}{l}\text { Morona Santi- } \\
\text { ago }\end{array}$ & ECU-19102 & Napo & ECU-19136 & Pastaza & & \\
\hline ECU-18556 & Manabí & ECU-17627 & $\begin{array}{l}\text { Morona Santi- } \\
\text { ago }\end{array}$ & ECU-19103 & Napo & ECU-19137 & Pastaza & & \\
\hline ECU-18561 & Manabí & ECU-17628 & $\begin{array}{l}\text { Morona Santi- } \\
\text { ago }\end{array}$ & ECU-19104 & Napo & ECU-19138 & Pastaza & & \\
\hline ECU-18564 & Manabí & ECU-17640 & Esmeraldas & ECU-19105 & Napo & ECU-19139 & Pastaza & & \\
\hline ECU-18566 & Manabí & ECU-17730 & $\begin{array}{l}\text { Zamora } \\
\text { Chinchipe }\end{array}$ & ECU-19106 & Napo & ECU-19140 & Pastaza & & \\
\hline \multirow[t]{9}{*}{ ECU-18567 } & Manabí & ECU-18407 & Manabí & ECU-19107 & Napo & ECU-19141 & Pastaza & & \\
\hline & & ECU-18495 & Manabí & ECU-19108 & Napo & ECU-19142 & Pastaza & & \\
\hline & & ECU-18510 & $\begin{array}{l}\text { Santo Do- } \\
\text { mingo de los } \\
\text { Tsáchilas }\end{array}$ & ECU-19109 & $\begin{array}{l}\text { Francisco de } \\
\text { Orellana }\end{array}$ & ECU-19143 & Pastaza & & \\
\hline & & ECU-18517 & $\begin{array}{l}\text { Santo Do- } \\
\text { mingo de los } \\
\text { Tsáchilas }\end{array}$ & ECU-19110 & $\begin{array}{l}\text { Francisco de } \\
\text { Orellana }\end{array}$ & ECU-19144 & Pastaza & & \\
\hline & & ECU-18522 & $\begin{array}{l}\text { Santo Do- } \\
\text { mingo de los } \\
\text { Tsáchilas }\end{array}$ & ECU-19111 & $\begin{array}{l}\text { Francisco de } \\
\text { Orellana }\end{array}$ & ECU-19145 & Pastaza & & \\
\hline & & ECU-18529 & Manabí & ECU-19113 & $\begin{array}{l}\text { Francisco de } \\
\text { Orellana }\end{array}$ & ECU-19146 & Pastaza & & \\
\hline & & ECU-18533 & $\begin{array}{l}\text { Santo Do- } \\
\text { mingo de los } \\
\text { Tsáchilas }\end{array}$ & ECU-19114 & Sucumbíos & ECU-19147 & Pastaza & & \\
\hline & & ECU-18535 & $\begin{array}{l}\text { mingo de los } \\
\text { Tsáchilas }\end{array}$ & ECU-19115 & Sucumbíos & ECU-19148 & Pastaza & & \\
\hline & & ECU-18542 & Manabí & ECU-19116 & Sucumbíos & ECU-19149 & Pastaza & & \\
\hline
\end{tabular}

